\title{
Naar een "kwaliteitssysteem" in de huisartsgeneeskunde
}

Citation for published version (APA):

Grol, R. P. T. M. (1991). Naar een "kwaliteitssysteem" in de huisartsgeneeskunde. Nederlands Huisartsen Genootschap. https://doi.org/10.26481/spe.19910927rg

Document status and date:

Published: 27/09/1991

DOI:

10.26481/spe.19910927rg

Document Version:

Publisher's PDF, also known as Version of record

\section{Please check the document version of this publication:}

- A submitted manuscript is the version of the article upon submission and before peer-review. There can be important differences between the submitted version and the official published version of record.

People interested in the research are advised to contact the author for the final version of the publication, or visit the DOI to the publisher's website.

- The final author version and the galley proof are versions of the publication after peer review.

- The final published version features the final layout of the paper including the volume, issue and page numbers.

Link to publication

\footnotetext{
General rights rights.

- You may freely distribute the URL identifying the publication in the public portal. please follow below link for the End User Agreement:

www.umlib.nl/taverne-license

Take down policy

If you believe that this document breaches copyright please contact us at:

repository@maastrichtuniversity.nl

providing details and we will investigate your claim.
}

Copyright and moral rights for the publications made accessible in the public portal are retained by the authors and/or other copyright owners and it is a condition of accessing publications that users recognise and abide by the legal requirements associated with these

- Users may download and print one copy of any publication from the public portal for the purpose of private study or research.

- You may not further distribute the material or use it for any profit-making activity or commercial gain

If the publication is distributed under the terms of Article $25 \mathrm{fa}$ of the Dutch Copyright Act, indicated by the "Taverne" license above, 
NAAR EEN 'KWALTTEITSSYSTEEM'

NN DE HUUSARTSGENEESKUNDE 


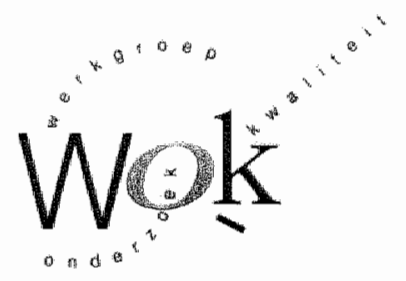

(3)

R. Groll 1991

Niets uit dezo uitgave mag worden verveelvoudigd eal of openbaar genalakt worden door middel yan druk, fotokopie, microfilm, geluidwband of op welke andere wijze ook, zonder vowrafgande schriftelijke toestemming wan de copyright-houder.

Produktio: Nederiandin Huisartisen Gisnootsethap Postbus 3231 3402 GE Uirectat

Druk: Drukkerij Quilek pirint BW. Nijimegen

CIP-GEGEVENS KONTNKLUK BHBLOTHEEK, DEN HAAG

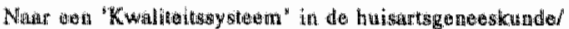

R. P. Th.M. Grol. - Utrech: Nederinats. Hunartaen Genoousehap. - III.

Mel hiteratuturopgave

ISBN 90.71714020 .9

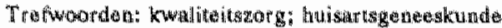




\title{
NAAR EEN 'KWALTTETSSYSTEEM' IN DE GUISARTSGENEESTUNDE
}

\author{
Mr. dr. R. P. Th. M. Orol
}

\section{REDE}

uitgesproken bij de aunwarding wan het ambt van bijonder hoogleraar in de hulsartsgeneeskunde, in het bijzonder de kwaliteitsbewaking en -bevordering in de huisartsgeneeskumde, vanwege het Nederlands Huisartsen Genootschap, aan de Katholieke Universitet Nimegen en de Rijksuniversiteit Limbiurg op vrijdag 27 september 1991. 
Mijnheer de Recior wan de Karholieke Universiteit Nimegen,

Mijnheer de Rector wan de Rijlswiversiteit Limburg.

Zeer gewaardeerde toehoorders,

De leerstoel waarvoor ik vandiag mijn openbare les uitspreek heeft betrekking op de kwaliteit van zorg die in de huisartspraktijk aan patiënten wordt geboden. Het is niet vreemd dat sommigen er moeite mee hebben zich hier iets concreets bij voor te stellen. Als ik de kwaliteit in de patientenzorg omschrijf als de juiste dingen op de juiste wijze doen, als de overeenkomst tussen wenselijke en feitelijke zorg of als patiënten die zorg geven die ze echt wensen en nodig hebben, heb ik u niet veel verder geholpen. Het woord 'kwaliteit' hoort zonder meer bij de meest misbruikte en verhullende termen die op dit moment in de mode zijn. In bijna alle sectoren van de samenleving gebruikt men het woord vooral als wapen in de strijd om anderen te overtuigen van de schoonheid, degelijkheld of voortreffelijkheid van de eigen koopwaar. Ik zal U werder een verhandeling over het kwaliteitsbegrip besparen. Liewer wil ik proberen $U$ de komende minuten een sehets te geven wan het werkveld van de kwaliteitsbewaking en bevordering in de huisartsgeneeskunde. In het bijzonder hoop ik haar plaats op het grensvlak van de medische weterischap, het gezond heidszorgbeleid en de medische praktijk aan te geven. Sinds mijn intrede in de huisartsenwereld heeft dit grensgebied mij steeds bijzonder aangetrokken en ik ben blij dat ik daar nu mijn academisch werkveld heb gevonden.

\section{KWALITEITSSYSTEMEN}

Een beleidsmatig kader voot het werkveld van de kwaliteitsbewaking en -bevordering kan men vinden in de nota $\mathrm{K}$ waliteit van Zorg die de staatssecretaris van Vollkggezondheid onlangs naar de Tweede Kamer zond (1). Daarin staat dat de overheid zorg op 'verantwoord niveau' verwacht van onder meer de huisartsen. Met 'werantwoord niweau' bedoelt men dat de zorg beantwoordt aan een reële behoefte van de patiënt, inhoudelijk van goed niveau is en zowel doelmatig als patièntgericht wordt verleend. De beroepsgroep mag zelf invulling geven aan wat dat precies inhoudt. Wel vraagt men van gezondheidszorginstellingen het opzetten van 'kwaliteitssystemen'. Van Dale volgend zou dit betekenen dat er een geheel van regels, afspraken en maatregelen moet komen ten behoeve van de bewaking, beheersing en verbetering van de kwaliteit van de patiëntenzorg. Een goede informatievoorziening over die zorg neent daarin een centrale plaats in.

Ook binnen de huisartsgeneeskunde zullen kwaliteitssystemen opgezet moeten worden. De aanzetten daartoe zijn aanwezig. Nederlandse huisartsen verlenem zorg op hoog niveau. Ze blinken wit, wergeleken mat andere landen en andere medische professies, wat betreft hum vaardigheid kwaliteitsmaatstaven voor hun werk op te stellen en wat betreft hun bereidheid elkaars werk onderling kritisch te toetsen. Er is een voortreffelijke opleiding tot huisarts. Door de Landelije Huisartsen Vereniging, het Nederlands Huisartsen Genootschap en de universitaire huisartseninstituten wordt vanaf de zeventiger jaren gesta.ag en betrekkkelijk eendrachtig aan $z 0^{\prime} n$ kwaliteitssysteem gewerkt en er zijn veel resultaten geboekt (2-7). Dit mag opmerkelijk en bijzonder genoemd worden voor een beroepsgroep, die lang gekenmerkt werd door solisme en die -zeker in de ogen van buitenstaanders- een zekere eigenzinnigheid en soms eigenwijsheid niet ontzegd kon worden.

De huisartsgeneeskunde als professie is in goed 30 jaar uitgegroeid tot een wolwaardig specialisme. Die snelle groei kan men onder meer aflezen aan de ontwikkelingen birnen de 
wetenschappelijke wereniging. In 1956 bij de start van het Nederlands Huisartsen Genootschap waren zo"n 400 huisartsen lid en had men $f 20.000$, op de begroting (8). Nu heeft men bijna 4000 leden en een begroting van ettelijke miljoenen. De eerste weterischappelijke daad van het beginmende Genootschap was een schriftelijke enquête onder haar leden naar de behoefte aan kwaliteitsbevordering. Nu werken er zo'n 40 mensen in dienst wan het Genootschap aan thet scheppen wain de voonwaarden voor een betere kwaliteit in de huisartsenzorg.

Ondanks deze positieve ontwikkelingen zal er nog veel werk verzet moeten worden. Ik beschouw- en dat is mijn boodschap yoor vandaag- het verder ontwikkelen en invoeren van een huisartsgeneeskundig kwaliteitssysteem als een van de grote uitdagingen voor de huisartsgeneesikunde voor de komende 10-20 jaar. Het succes hiervan kan belangrijke consequenties hebbien voor de plats van de huisartsgeneeskunde in de snel veranderende gezondheidszorg.

In deze openbare les wil ik de huidige ontwikkelingen op het gebied van kwaliteit van zorg in de huisartsgeneeskunde kort op een rij zetten en me vervolgens afvragen, welke werdere stappen er nodig zijn op weg naar zo'n kwaliteitssysteem. Welke knelpunten zijn er en welke mogelijkheden woor verdere ontplooing liggen er? Daarbij wil ijk ook aandacht besteden aan de mogelijkheden die deze leerstoel en de interuniversitaire Werkgroep Onderzoek Kwaliteit Huisartsgeneeskunde van de universiteiten van Nijmegen en Maastricht (WOK) hierbij kunnen bieden. Onze taak zie ik vooral in het bieden van een wetenschappelijke onderbouwing van dit kwaliteitssysteem; in het leveren van een bijdrage aan het ontwikkelen en onderzoeken van de methoden, technieken en procedures die hierbij nodig zijn. Daarvoor is wetenschappelijk onderzoek nodig, dat ten dele toegepast, ten dele funderend van karakter is. Ik zal onze actiwiteiten beschrijven aan de hand van drie kernactiviteiten in een huisartsgeneeskundig kwaliteitssyteem: de ontwikkeling van richtlijnen voor kwaliteit in de zorg, de systematische toetsing of evaluatie van die kwaliteit en de kwaliteitsverbetering.

Tevoren will ik kort ingaan op een dilemma waar huisartsen bij het organiseren van kwaliteit mee te maken kunnen krijgen.

\section{EEN DILEMMA IN HET ORGANISEREN VAN KWALITEIT}

Kwaliteit is een relatief begrip; het is subject- en contextgebonden, hetgeen wil zeggen dat het veel uitmaakt wie op welk moment waarover een kwaliteitsoordeel vitspreekt (9). Verschillende partijen in de gezondheidszorg - patiënten, huisartsen, specialisten, werzekeraars, beleidsmakers, paramedici- hebben verschillende opvattingen over goede zorg op basis van hun specifieke belangen. Die opwattingen hoeven niet te conflicteren, maar doen dat soms wel. Ook de opvattingen over de wijze waarop de kwaliteit van zorg het beste gegarandeerd kan worden kurnen uiteenlopen (Tabel 1).

De samenleving (beleidsmakers, verzekeraars) wil waar voor zijn geld en wil toegankelijke, patiëntyriendelijke en doelmatige zorg. Ze oefent in toenemende mate druk uit op huisartsen on aan de thand van gegevens hun werkwijze zichtbaar te maken $(10,11)$. Het ontwikkelen van kwaliteitsrichtijnen ziet ze daarbij als een weg naar grotere uniformiteit en als een middel tot sturing van de zorg. Ze is geinteresseerd in productiecijfers op geaggregeerd niveau en in gegevens over variaties in de zorg tussen praktijken. Daarmee kan ze praktijken die mogelijk onvoldoende kwaliteit leveren identificeren. Aan het sturen van de 
kwaliteit hoopt ze een bijdrage te leveren via regelgeving, beloning, sancties en externe toetsing.

Huisartsen daarentegen zijn, wat betreft het bieden van verantwoorde zorg asn hun patiënten, weel meer geinteresseerd in effectieve en toepasbare diagnostische en therapeutische procedures. Kwaliteitscriteria zien ze als hulpmiddel daarbij, maar niet als iets war ze op wastgelegd willen worden (12). Daartoe spelen teveel indiwiduele, aan de persoon en diens situatie gebonden factoren een rol in de problemen van patiënten (13). Wensen en meningern wan patiënten zijn, bij de keuze voor cen aampak, vaak doorsiaggevend. Huisartsen zijn veelal serieus met kwaliteitsverbetering bezig, maar doen dat bij voorkeur door onderling, in eigen kring met collegae, hun handelen kritisch te bespreken en door, via nascholing; hun vak bij te houden.

Tabel 1: Opwattingen van de samenlewing en huisartsen over kwaliteitsbewaking en -bewordering

\begin{tabular}{|c|c|c|}
\hline activiteit & samenleving & huisartsen \\
\hline * richtlijnen & $\begin{array}{l}\text { - doelmatigheid } \\
\text { - toegankelijkheid } \\
\text { - bejegening } \\
\text { doel: uniformiteit, sturing van } \\
\text { zorg }\end{array}$ & $\begin{array}{l}\text { diagnostische en } \\
\text { therapeutische } \\
\text { procedures } \\
\text { doel: houvast byj werk }\end{array}$ \\
\hline * toetsing & $\begin{array}{l}\text { - produktiecijfers } \\
\text { - aggregatie } \\
\text { - variatie in zorg tussen prak- } \\
\text { tijken }\end{array}$ & $\begin{array}{l}\text { - gegevens op patièntniveau } \\
\text { - individuele en groeps- } \\
\text { lacunes }\end{array}$ \\
\hline * verbetering & $\begin{array}{l}\text { - regelgeving } \\
\text { - beloning/straf } \\
\text { - externe toetsing, selectie }\end{array}$ & $\begin{array}{l}\text { - educitie } \\
\text { - onderlinge toetsing } \\
\text { - ondersteuning }\end{array}$ \\
\hline
\end{tabular}

Huisartsen moeten, waar het de bewaking van de kwaliteit betreft, dus cen weg zien te vinden in het spanningsveld tussen wensen van de patiënt, eisen van de samenleving en de eigen werantwoordelijkheid als medische professional $(14,15)$. Meestal gaat dit goed. Het is echter niet ondenkbaar dat de belangen op gegeven moment sterk uiteen gaan lopen. Een vooridurende en intensieve communicatie over el kaars bedoelingen en opinies is nodig om te voorkomen dat men elkaar met wantrouwen gaat benaderen. Zo is er zeker bij een deel van de huisarsen al sprake van een angst dat verzekeraars, overheid of patienten misbruik zouden kunnen gaan maken van de kwaliteitsrichtijnen die nu door de beroepsgroep wor* den opgesteld (12). De reactie die de uitspraak van een inspecteur van de Volksgezondheid ower de kwaliteit van huisartsen onlangs opriep is daarvan een treffend voorbeeld. 
Het sus belanghile dat er wen kwliteitsystem wordt opgezet, wawin zowel beleidsmawers, patienten wis hisarten zich hunen herkennen. Huisartsen zullen zich moeten reall-

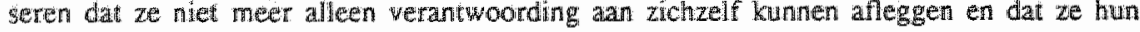
werk ook inzichtelik moeten maken voor "buiterstaanders".

Andertjos zullen beleidsmakers en patuentenorganisaties zich dienen te realiseren dat bepadde werwachtingen ten anzien wan husartsen niet realistisch zijn en dat een te grote Gruk van bovenaf wel eens volledig contraproductie kan werken. De ervaringen daarmee in de Verenigde staten onlokte Berwick de steilling, dat controle van bovenaf om de kwaliteit te bevorderen op zijn best ineffichent is en op zijh slechtst een gegarandeerde mishikking intioude (16).

Laten we ma deze conclusie nu eens naar het kwaliteitssysteem in de huisartsgeneeskunde kijlexin.

\section{RICHTLIINEN VOOR DE PRAKTLJK}

Een eerste peiler bij het opzetten vam een kwalteitssysteem is het formuleren van kwaliteitsrichtlinen oftewel richtijnen voor "verantwoorde zorg". On tot zulke richtijinem te komen zijn goede gestructureerde methoden nodig, zgn. 'consensusprocedures'. Er bestaat een groot aantal, qua doelstelling en methodiek, verschillende procedures op dit gebied (17 20). Ze hebben gemeenschappelijk dat ze de wetenschappelijke literamur op een bepaald lerrein zo goed mogelijk proberen te bundelen en, waar deze literatuur geen oplossing biedt, ervaringen tilt de praktijk als aanvulling gebruiken. Ook wordt meestal getracht een zo breed mogelijk draagwak voor de richthinen te verwerven onder degenen die ze moeten gaan toepassen.

\section{Siondaarden}

In de huisartsgeneeskunde worden kwaliteitsrichtlijnen oftewel 'standaarden" met een brede, landelijke geldigheid opgesteld door het Nederlands Huisartsen Genootschap (21). Er wordt een zorgvuldige procedure gehanteerd, waarin zoveel mogelijk expertise, ook van specialisten, wordt ingewonnen en warbij de richthinen tevens op hum haalbaarheid in het dagelijks werk worden getoetst. Binnen de huisartsgeneeskunde is dit een unieke ontwikkeling. Nergens ter wereld windt men een zo goed uitgewerkte consensusprocedure om landelijk geldende richtlijnen voor het huisartsgeneeskundig handelen op te stellen. Nederlandse huisartsen staan er zeer positiet tegenover, zo bleek uit enquêtes onder landelijke steekproeven van husartsen $(12,22)$. De grote meerderheid vindt zulke richilinen, ook na twee jaar now, van belang als houvast in het werk, als een professionele verantwoordelijkheid en als middel om meer eenheid in het werk van huisartsen te kriggen. Minder dan 10\% van de huisartsen vindt ze slecht toepasbaar in het dagelijks werk.

De richtilinen van het Genootschap dragen in sterke mate bij aan de emancipatie van de Huisartsgeneeskunde. Ze maken duidelik dat huisartsen goed in staat zijn zelf te bepalen wat adequaat handelen in hun eigen werksetting is. Huisartsen laten een eigen geluid horen dat nogal eens wan dat van specialisten afwijk. Tegen de mening van veel specialister in werd bijvoorbeeld het aanvragen van een echografie bij een dregende miskraam niet als richtlijn voor her handelen van de huisarts opgenomen. Voor de opsporing en behandeling wan sen te hoog cholesterolgehalte formuleren huisartsen eigen richtlijnen, die deels afwij- 
ken van de woorstellen van specialisten op dit terrein. Dexe onafhankelijke houding wordt (nog) niet door alle specialisten met applaus begroet. Veel huisartsen moeten er rall ook nog aan wennen. Echter beide partijen aullen naar mijn mening op den duur beter af zijn met huisartsen die vol zelfvertrouwen de discussie ower de onderlinge taakafbakening en afstemming van de zorg kunnert en durven aangaan.

\section{Knelpunten in de ontwikkeling van richtijnen}

Ondanks deze positieve ontwikkelingen is het zinnig om kritisch te blijwen bezien waar verbetering mogelijk is. Recent zijn er nogal wat publikaties verschenen over de ontwikkeling van praktijkrichtijnen, waarin op mogelijke valkailen en lacunes in de methodologie wordt gewezen (o.a. 14,17-20, 23-26). Daarin komen wragen naar woren die ook de NHGprocedure geiden en die nader onderzacht zouden moeten worden. Onze interuniversitaire werkgroep hoopt een bijdrage aan het beantwoorden hiervan te kunnen geven. Ik wil er slechts enkele noemen:

- Er bestaan veel verschillende consensusmethoden; de vraag welke procedure de beste en meest betrouwbare resultaten oplevert is nog lang niet beantwoord;

- Binnen een ontwikkelingsprocedure is een systematische analyse van de wetenschappelijke literatuur een centrale activiteit. Het is nog niet duidelijk hoe dit het beste kan plaatsvinden en of de zogenaamde 'meta-analyse' daarin superieur is.

- Formalisering van de consensusdiscussies van de opstellers en andere betrokkenen is nodig, aangezien groepsprocessen een belangrijke rol spelen en dominante personen met uitgesproken meningen gemakkelijk doorslaggevend kunnen xijn. De vraag is hoe men dit kan voorkomen en hoe bruikbaar anonieme stemprocedures en Delphi-methoden hierin zijn.

- Een heldere, eenduidige formulering is nodig, zodat verschillende gebruikers de richtlijnen op dezelfde wijze interpreteren. In een analyse die wij op de teksen van enkele 'standaarden' uitvoerden bleek dat de standaard diabetes $33 \%$ zimen met vage, onduidelijke richtilinen bevatte, die voor urineweginfecties maar $11 \%$.

- De status en reikwijdte van de richtlijnen zijn vaak niet duidelijk. Sommige richtlijnen zijn beter en harder onderbouwd en kumen daarom meer dwingend zijn in hun aanbevelingen voor de praktijk. Andere berusten meer op opinies en ervaringen en laten daarom veel meer keuzevrijheid aan zowel de arts als de patiënt. Wat betreft de standaard wan het Huisartsen Genootschap voor de behandeling van diabetes mellitus type II heeft wetenschappelijk onderzoek duidelijk uitgewezen dat een acceptabel niveaus van het bloedsuikergehalte complicaties aan ogen en woeten bij diabetespatiënten kan voorkomen. De aanbeveling dat de huisarts voor zijn diabeten een actieve bewaking organiseert, elke drie maanden de bloedsuikerwaarde bepaalt en een aparte diabetespatienntenkaart gebruikt is vooral terug te voeren op gezond verstand en klinische ervaringen. Informatie over de effecten hiervan op de gezondheid van patiënten missen we nog. Eigenlijk zouden richtijnen voor de praktijk van informatie over de hardheid van de aanbevelingen vergezeld dienen te gaan $(23,27)$.

In het verlengstuk hiervan ligt het probleem dat een systematische evaluatie van de toepassing en de effecten van de richtlignen in de echte praktijk nog vaak achterwege blijft. De toepassing van richtlijnen ontleend aan goed opgezette klinische trials kan irrelevant zijn in de doorsnee praktijik, gezien de aard van de werksetting, de kenimerken van de patiëntenpopulatie, de beschikbaarheid van apparatuur, de werkdruk en andere factoren (28). Op dit gebied is veel meer onderzoek nodig. Hier ligt mijns inziens ook een goede aansluiting tussen het patiëntgebonden onderzoek en het werkveld 
van de kwaliteitsbewaking en bewordering. In de Cara-standaard bijwoorbeeld die nu in ontwikkeling is zal exen weel nauwkeurger bewaking en begeleiding wan Cara-patiënten door de huisarts worden voorgestielld dan momenteel in de meeste huisartspraktijken wordt geleverd. Er is nog nawwelliks iets bekend ower de toepasbaarheid en effecten van dexe aanbeveling binnen de doorsine huisartspraktijk.

\section{Consensus als oplossing voor onzekerheid}

Skrabanek (29) formuleerde in een editorial in de Lancet het probleem van consensusprocedures als volgt. Consensusworming, zegt hij, wordt gebruikt om zaken waar men onzeker over is op te lossen door middel van compromissen. Onzekerheid vindt men in de geneeskunde, net als in de theologie, namelijk moeilijk te tolereren. Een consensusprocedure wordt, net als vroeger een synode van bisschoppen, in gang gezet om tot een uitspraak te komen. Het gevaar is datt onacceptabele zorg de uitkomst van het compromis is. Ironiserend geeft hij als voorbeeld de wijze waarop men in thet oude China een meningsverschil over de lengte van de neus van de keizer trachtte op te lossen. Niemand was het toegestaan het gezicht van de keizer te zien. Daarorn ging men het keizerrijk rond en vroeg alle wijze mensen een schatting van de lengte van diens neus te geven. Door her gemiddelde te memen slaagde men or in een acceptabel compromis te bereiken.

We moeten serieus naar dit commentaar luisteren. Een van de gevaren van consensusprocedures is naar mijn mening dat de stelligheid waarmee vroeger de grote leermeesters hun uitspraken over goede kwaliteit van zorg deden, vervangen is door de meer democratische stelligheid waarmee thans een consensusgroep zijn uitspraken doet. De pretentie ten aamzien van de geidigheid van de uitspraken is er mogelijk nog groter op geworden. Eerder beschreef ik de consensusprocedure als een ritueel, bedoeld om tol bruikbare afspraken over de patiëntenzorg te komen. Rituelen zijn vaak functioneel binnen de setting, waar ze worden toegepast. Ik beschouw de consensusprocedure in de huisartsgeneeskunde ook als een uiterst nuttig en noodzakelijk ritueel. Een voortdurende kritische houding ten aanzien van de consensusmethode en haar uitkomsten is echter gewenst. Men dient de beperkingen ervan in de gaten te houden. Niet-medici willen de doelen van zulke richtlijnen nog wel eens verder leggen dan feitelijk verantwoord is. $\mathrm{Zij}$ zullen zich moeten realiseren dat ze de 'state-of-the-art', het beste advies wan dit moment, weergeven en geen absolute waarheden. En dat ze enige tijd later toch onjuist, niet haalbaar of niet effectief kunnen blijken te zijn (27).

\section{KWALITEITSTOETSING}

Een tweede belangrijk gebied in een kwaliteitssysteem is het organiseren van kwaliteitsmetingen of kwaliteitstoetsing. Hieraan is een viertal activiteiten te onderscheiden: het selecteren van indicatoren of aspecten waaraan men de kwaliteit van zorg wil afmeten; het verzamelen van gegevens over de zorg; het analyseren van die gegevens en nagaan in hoeverre volgens geaccepteerde kwaliteitsrichtlijnen wordt gewerkt en tenslotte het geven wan overzichtelijke feedback over de resultaten van de toetsing, zodat men de zorg in de gewenste richting kan verbeteren. In een systematische kwaliteitstoetsing kan men niet alles meten, men dient zich tot de essentiële aspecten te beperken. Bij de zorg voor diabetespatiënten is dat bijyoorbeeld de instelling gemeten via de bloedglucosewaarde. Een voorbeeld van een cenvoudige kwaliteitstoetsing: Höppener e.a. (30) vroegen de 15 huisartsen wit het Registratienet Huisartspraktijk van de Rijksuniversiteit Limburg om van al hun diabeten de laatste 
twee glucosewaarden uit hun patientenkaart op te zoeken. Deze werden op een geautoraatiseerd invulformulier vermeld, wama de formulieren centragl werden verwerkt. Hieruit bleek dat $37 \%$ van de patienten onvoldoende ingesteld was (grens 10 mmol/1). Voot de deeinemende huisartsen was dit geen bevredigende uitkomst en cen aanzel de diabeteszorg nader onder de loep te taemen. Aangezien deze hwisartsen basale gegevens van hun pati enten in de computer hebben opgeslagen, kostte het verzamelen van de gegevens gemiddeld niet meer dlan een half uur tijd.

\section{Instrumenten ent procedures}

Het uitvoeren van een systematische kwaliteitstoetsing vraggt on praktisch hanteerbare instrumenten en procedures. Wia wetenschappelijk onderzoek in de huisartsgeneeskunde zijn er de afgelopen jaren all tal wan instrumenten en procedures op uiteenlopende terreinen binnen de huisartsgeneeskunde ontwikkeld. Deze zijn echter miet zonder meer toepasbaar bij een systematische en regelmatige kwaliteitstoetsing door huisartsen zelf in hun eigen werksetting. Een dergelijk gebruik stelt specifieke eisen. Verschillende auteurs spreken hun verbazing erover uit hoe weinig energie er tot nu toe is gestoken in het formuleren van praktisch bruikbare indicatoren en meetprocedures voor de kwaliteit van de zorg (31). Berwick schreef hierover: 'Ondanks een lange intellectuele traditie in het onderzoek naar kwaliteit in de laatste 30 jaar, missen we bijna volstrekt een hanteerbare toegepaste technologie voor het meten en toetsen wan de kwaliteit in de zorg' (32).

Binnen de huisartsgeneeskunde in Nederland is deze uitdaging mijns inziens goed opgepakt. Het onderzoeksprogramma van onze interuniversitaire werkgroep levert daaraan, samen met tal van anderen, een belangrijke bijdrage. Er zijn op dit moment toetsingsprocedures in ontwikkeling op het gebied wan het medisch handelen van de huisarts, de consultvoering, de arts-patiëntcommunicatie, de voorlichting aan patiënten, de praktijkvoering en -organisatie, de registratie, het voorschrijven van medicijnen, de medische kennis en de technische vaardigheden van huisartsen, het preventief handelen en tenslotte de evaluatie door patienten van de zorg in de huisartspraktijk.

Het Nederlands Huisartsen Genootschap heeft een Commissie in het leven geroepen, welke een inhoudelijk raamwerk voor kwaliteitstoetsing van Nederlandse huisartsen moet uitwerken en de verdere ontwikkeling van instrumenten en procedures moet coördineren.

\section{Een systemarische kwaliteitstoetsing}

Kortom, de ontwikkeling van een bruikbare methodologie is in volle gang. Daarbij dienen zich echter ook problemen aan die on nadere uitwerking en onderzoek vragen:

- het zogenaamde 'dekkingprobleem': het is nog niet duidelijk welke aspecten van thet huisartsenwerk getoetst zouden dienen te worden om een walide, representatief bec:ld te krijgen wan de gehele kwaliteit van zorg in de huisartspraktijk. Het probleem wan de selectie van essentiële aspecten moet met prioriteit door de beroepsgroep aangepakt worden

- de nadruk ligt verder nog relatief sterk op de toetsing van de competentie van huis artsen en minder op de feitelijke zorg die in een praktijk wordt geleverd

- wetsing van de effecten wan de zorg op het welbevinden, het ziektegedrag of de tevrew derheid van patiënten is nog nauwelijks gemeengoed in de huisartsenpraktijk

- kwaliteitstoetsing wordt nog vaak gezien als een ad hoc gebeurtenis; er bestaat veel minder ervaring met kwaliteitstoetsing als een continue activiteit binnen de normale praktijkwerkzaamheden 
- en kwalhiteilstoetsing wordt väalk gexien als iets van de hunisarts en minder alis iets van de praktijk $k_{j}$ war alle medewerkers in de praktijk medeverantwoordelijk voor zijn.

Als men er in zou slagen een systematische, contirue en multi-dimensionele verzameling en analyse vari gegewenis over de zorg op praktijkniveau te organiseren, dan heeft men tegelijkertijd een goede basis voor de verplichte intercollegiale toetsing in een waameen- of huisartsengroep, die birnen enkele jaren gerealiseerd dient te zijn. Tevens kan men dan een bijdrage leveren aan geaggregeerde gegevens op regionaal en landelijk niveau, welke de beleidsmakers en vertekeraars bij hun beleid kunnen helpen. Op deze wijze kan een systematische kwaliteitstoetsing zowel de leerbehoefte van huisartsen als de behoefte van de samenlewing om meer inzicht in de zorg te krijgen bevredigen.

Ervaringen in Engeland en de Verenigde Staten hebben inmiddels bruikbare uitgarigspunten voor zo'n toetsing op praktijkniveau opgeleverd (33-37). Een experiment in een groepspraktijk in Engeland toonde bijvoorbeeld dat met een investering van 4 uur per week en een kostenfactor van minder dan $f 4000^{-}-$per jaar een assistente een groot aantal gegevens kan verzamelen (38).

Ik pleit hier dus voor verder onderzoek naar de wijze waarop zo'n kwaliteitsitoetsing op werschillende niveau"s en vooral op het niveau van de huisartsenpraktijk kan worden georganiseerd. De praktijk is binnen de huisartsgeneeskunde de eenheid waar de zorg aan patienten wordt gelewerd en on die zorg draait het uiteindelijk allemaal. In het onderzoeksprogramma van de interuniversitaire werkgroep haken we hier op in door samen met anderen te werken aan verschillende toetsinstrumenten en procedures met een nationale en soms een internationale geldigheid. Zo werwachten we veel van een gecomputeriseerde toetsing van thet medisch handelen. Samen met de afdelling Medische Informatica en Epidemiologie te Nijmegen en met de beroepsorganisaties ontwikkelen we een expert-programma, waarmee huisartsen -alleen of met collega's- wia de computer kunnen toetsen in hoeverre ze de kwaliteitsrichtlijnen van het Nederlands Huisartsen Genootschap volgen. Een integratie van dit programma binnen de Huisarts Informatie Systemen moet een eenwoudige en aantrekkelijke toepassing binnen het normale werk garanderen.

Samen met het NIVEL zijn we bezig met het vormen van een representatieve groep over het land verspreide praktijken, die zullen gaan fungeren als informatiebron wat betreft de kwaliteit van de zorg. In die praktijken zullen geautomatiseerd, op min of meer continue basis, gegevens over de verleende zorg worden verzameld. Gegevens die zowel aan huisartsen zelf, ten behoeve van hun kwaliteitsbevordering, als aan andere partijen in de gezondheidszorg een genuanceerd beeld van de kwaliteit van de patiëntenzorg in de huisartsgeneeskunde kunnen bieden.

\section{KWALITEITSVERBETERING}

Ongetwiffeld het meest complexe onderdeel van het organiseren wan kwaliteit is het op gang brengen wan daadwerkelijke verandering en verbetering in de praktijkroutines, als dat nodig is. Veranderen is moeilijk, daarin onderscheiden huisartsen zich in het geheel niet van hun patiènten die hun leefstijl moeten aanpassen of adviezen en voorschriften van hun huisarts moeten opvolgen. Uit tal van studies is inmiddels duidelijk dat inzichten, richtlijnen of teclmieken die bij kunnen dragen aan een betere kwaliteit van zorg, maar langzaam ingang 
vinden. Cok al zijn artsen ervan op de hoogte dan is dat geen garante dat ate we praktijk worden toegepast.

"Wellicht hebben we teveel wertrouwen gehad in een model dat een ratuonete, nformatho zoekende. warschijnilikneden arwegende hulpverlener als kern had, wayroor wy dachten dat alleen all de beschikatrheid van nieuwe informatie zou leiden tot een bijstelling van het medisch handelen' concluderen Lomas en collega's (39) na een analyse van de literatur op dit gebied.

Bünnen de huisartsgeneeskunde zijn de laatste tijd beduidende stappen gezet op weg mar een goede ontwikkeling en organisatie van de kwaliteitsverbetering. Er wordt hard gewerkt aan een stabiele infrastructuur voor de deskundigheidsbevordering van huisartsen. If verschillende regio's zijn de exste stappen gezet op weg naar verregaande samenwerking en afstemming tussen alle betrokkenen op het gebied van de nascholing. De verwachting is verder dat intercollegiale toetsing binnenkort een gebrukelijke methode van verbetering van de zorg voor alle huisartsen is. Er worden programma's, toetsen en methodieken ontwikkeld gericht op echte praktijkverandering.

\section{Knelpunten}

Ondanks deze ontwikkelingen blijven er knelpunten waaraan gewerkt zou dienen te worden:

- in de eerste plaats is er nog onvoldoende balans tussen aandacht voor verbetering van de kenris en de attitude enerzijs en aandacht voor het feitelijk handelen van huisartsen anderzijds. Methoden voor kentis- en attitudeverandering kennen een langere traditie en zijn veel beter witgewerkt. Daar gaat ook het meeste geld naar toe. Men dient zich echter te realiseren dat zulke methoden hooguit een eerste stap in cen veranderingsproces zijn. Zich hiertoe beperken is weggegooid geld. Het advies aan automobilisten bijwoorbeeld om in een drukke woonwijk de snelheid te matigen wordt feitelijk ook alleen maar geeffectueerd als werkeersdrempels de automobilist daartoe dwingen.

- een tweede probleem is dat er nog te weinig aandacht wordt gegeven alan specifieke barnieres die belenmeren dat weranderingen tot stand komen. Die barrieres hebben maar ten dele met de huisarts te maker. In landelijke enquêtes onder aselecte steekproeven van huisartsen vroegen we naar de problemen die huisartsen hebben om bepalde standaarden en richtijnen van het Nederlands Huisartsen Genootschap op te volgen. Bij de diabeteszorg was dat bijvoorbeeld vooral het omschakelen naar een actieve bewaking van patiënten en het anpassen wan de praktijkvoering on die bewaking beter nogeijik te maken. Echter ook het feit dat een deel van de patiënten nog bij de specialist ondier controle is zagen sommigen als probleem. Bij het volgen van de richtijnen woor het handelen bij enkeldistorsic was het belangrijkste probleem volgens da huiswartsen dat patiënten - buiten de huisarts om - voor diagnostiek en behandeling naat het ziekenhuis gaan.

- een derde knelpunt tenslotte is dat we nog onvoldoende weten wat nu eigenlijk echt effectieve methodten zijn orm hel gedrag van artsen te beinvloeden. Onderzoek op dit gebied staat nog in de kinderschoenen, voldoet vak niet aan methodologische eisen en heeft meestal betrekking op moeilijk vergelijkbare interventies. Toch thebben de ontwikkelingen niet stil gestar $(39-42)$. Ik heb getracht de nu beschikbare inzichten op het gebied van de beinvloeding van routines van medici op een rij the zetten door ze te ordenen op de dimensie intrinsieke versus extrinsieke beinvloeding, of tewel naar de mate watrin ze vooral educatief en informatief dan wel wooral dwingend en sturend van karakter zijn (43). Dan blijkt dat de effecten van gedrukte informatie en massamediale 
voorlichting op gedragsverandering marginaal zijn. De invloed van cursussen en groepseducatie is twiffelachtig (Tabel 2).

Tabel 2: Effecten wan interventies orn praktijkroutines te beinvloeden.

\begin{tabular}{|c|c|c|}
\hline & & effect \\
\hline informatief & $\begin{array}{l}\text { * gedrukte materialen, tijdschriften, massamedia } \\
\text { * groepseducatie, cursussen } \\
\text { * persoonlijke instructie door collegae } \\
\text { * (intercollegiale) toetsing en feedback } \\
\text { * reminders } \\
\text { * barrieres } \\
\text { * praktijkvisitatie } \\
\text { praktische ondersteuning (materieel/personeel) } \\
\text { - beloning/straf } \\
\text { regelgeving, certificatie, contract }\end{array}$ & $\begin{array}{l}- \\
+1- \\
+ \\
+ \\
+ \\
+1- \\
? \\
? \\
+1- \\
?\end{array}$ \\
\hline
\end{tabular}

Meer onderzoek is nodig naar het effect van praktijkvisitaties, van praktische en materiële ondersteuning van buisartsen en van formele toetsing en regelgeving in het kader van herregistratie en contractering. Het meest effectief lijken momenteel de persoonlijke instructie eir ondersteuning door getrainde en gerespecteerde collegae, de intercollegiale toetsing en feedback en het gebruik van reminders. Vooral de computer kan bij bepaalde methoden een bruikbare steun geven.

In het onderzoeksprogramma wan de interuniversitaire werkgroep trachten we een bijdrage te leveren aan het ontwikkelen en testen van bruikbare en effectieve interventiemethoden om praktijkgedrag van huisartsen te beïnwloeden. Hiervoor is veel funderend onderzoek nodig. Ik zou er voor willen pleiten een deel van het geld dat nu in nascholing wordi gestoken te reserveren voor het onderzoek naar meer effectieve beìnwloedingsmethodieken. Vanuit het werleden hebben wij een bijzondere expertise en interesse in methoden van intercollegiale toetsing en feedback opgebouwd. Deze hopen we de komende jaren verder uit te bouwen. Daarnaast hebben we de aandacht gericht op het onderzoeken van de werkzaamheid van thet inschakelen van getrainde consulenten die een persoonlijke instructie en een praktische ondersteuning geven aan huisartsen en praktijkassistenten.

Dat een inhoudelijke toetsing en feedback door gerespecteerde collegae ook tot een aanzienlijke kosteribesparing kan leiden bewees het Diagnostisch Centrum in Maastricht. Vanaf 1985 krijgen alle 80 huisartsen uit de regio twee keer per jaar commentaar op het aanvragen van diagnostische tests. Volgt men de landelijke tendens dan waren de kosten voor testaarwragen in 1989 bijna 3,5 miljoen gulden geweest. De werkelijk kosten bleven echter onder de twee miljoen. Betrekt men ook de feedbackkosten erin dan is de schatting dat er in eén jaar ruim een miljoen is bespaard. 


\section{ORGANISATIE VAN KWALITEITSEEWAKTG EN VRRBETERING}

Tot nu toe ben ik vooral ingegaan op de methoden en techneken die men in een kwaliteitssysteem kan gebruiken. Ik wil eindigen met de vaag hoe men een systematische kwaliteits" bewaking en -verbetering kan organiseren en welke voorwaarden hiervoor aanwezig dienten te 2 ijn.

De organisatie wordt bij voorkeur op verschillende niveau's vorm worden gegeven (Tabel 3). Dat wril zeggen dat de richtlijnontwikkeling, de kwaliteitstoetsing en de kwaliteitsverbetering zowel op centraal, lokaal, praktik - en individueel niveau goed ingevuld dienen te worden. Op elk niweau zijn andere activiteiten door andere personen of instanties nodig. Onderling shiten deze activiteiten bij voorkeur zo goed mogelijk op elkat aan.

Tabel 3: Een huisartsgeneeshundig kwaliteirsysteem

\begin{tabular}{|l|l|l|l|l|}
\hline & centraal & lokaal & praktijk & individu \\
\hline kwaliteitsrichulijen & & & & \\
\hline kwaliteitstoetsing & & & & \\
\hline kwaliteitsverbetering & & & & \\
\hline
\end{tabular}

Het realiseren van zo'n kwaliteitssysteem vraagt om een substantiële investering in termen van geld, tijd, menskracht, opleiding, expertise en ondersteuning. In het bedrijfsleven gaat. men er vanuit dat investeren in kwaliteit zichzelf terugbetaalt. Men mag kosten verbonden aan de kwaliteit van zorg beschouwen als zorgkosten, immers patiennten hebben direct baat bij een verbetering ervan. Het spreekt dan ook vanzelf dat deze kosten doorberekend worden in de prijs van die zorg. Met een bijdrage van bijwoorbeeld een gulden per consult of visite of $f 4_{3}=$ per ingeschreven patiēnt per jaar, praten we over een bedrag van ongeveer 50 miljoen guiden of gemiddeld zo'n $f 10.000$,- per praktijk per jaar. Daarmee zou al een geweldige impuls aan de kwaliteitsbewaking en -verbetering gegewen kunnen worden. Dit zou dan ook moeten inhouden dat er per praktijk en per hulpverlener -uiteraard gecontroleerd-een omschreven tijd per week vrij wordt gemaakt voor individuele, lokale en vooral praktijk-gerichte kwaliteitsactiviteiten. Het gebruik van een medische module, het systematisch verzamelen en presenteren van gegevens over de zorg en het maken van een jaarverslag kan men daarbij als woorwaarden stellen.

\section{Opleiding}

Tenslotte - de nota Kwaliteit van Zorg van de staktssecretaris noem dit ook- is het essentieel dat werkers in de gezondheidszorg getraind worden in de methoden en technieken wan kwaliteitsbewaking en -bevordering. Werken aan kwaliteit moet door huisartsen erwaren worden als een normaal, vast onderdeel wan hun werk, net als het versturen wan rekeriingen aan patiënten. Dit vraagt een specifieke scholing en training van huisartsen. Het vraagt tevens expertise om de training en ondersteuning van huisartsen te verzorgen. Tot nu toe beschikken we nog onwoldoende over een kader van huisartsen on dit uit te voeren. Ik will dan ook sterk pleiten voor het opzetten, eventueel met andere belanghebbenden als het 
CBO, wan een gerichte opleiding van kwaliteitsbewakers en expers: op het gebied van kwalleitssytemen.

Er zijn inmidels ahuzetten op dit gebied gerealiseerd. In de experimentele SGO-kadertrajning die ordangs is gestart krijgt de expertise op het gebied van de kwaliteitsbevordering aandacht. In de regio"s rond Mastricht en Nijmegen zijn wpe vercter bezig huisartsen sleutelfiguren wit lokale netwerken - te trainen om de begeleiding van intercollegiale toetsing en kwaliteitsbevordering in groepen op zich te nemen en gaan we na of dit een realistische mogelijkheid iss. In mijn perceptie zijn echter verdere siagpen nodig. Voor heel Nederland auden $20^{\prime}$ 'n 100-150 huisartsen special getraind dienen te worden om, uiteraard tegen vergoeding, binnen hun eigen regio aan huisartsen ondersteuning te geven bij de organisatie van kwaliteit in hun praktijk en on methoden en nieuwe ontwikkelingen op dit gebied aan. te dragen.

Tenslotte is in het licht war een toenemende Europese samenwerking de uitwisseling met andere landen wan groot belang. In dat verband kan ik melden dat onze interuniversitaire werkgroep samen met het Nederlands Huisartsen Genootschap het initiatief heeft genomen tot een Europese werkgroep op het gebied van kwaliteit in de huisartsgeneeskunde en dat we hierbij de volledige steun hebben van de wereldorganisatie van huisartsen.

\section{SLOT}

Aan het eind van mijn betoog gekomen wil ik een en ander graag samenvatten met de constatering dat er al veel stappen zijn gezet op weg naar een huisartsgeneeskundig kwaliteitssysteem, maar dat er ook nog verdere activiteiten nodig zijn. IKk heb onder andere gepleit:

- voor een perfectionering van de huisartsgeneeskundige consensusprocedure en vooral voor het opzetten van onderzoek naar de toepasbaarheid en effecten van kwaliteitsrichtijnen in de doorsneepraktijk

- voor een systematische en continue gegevensverzameling en kwaliteitstoetsing op het niweau van de thuisartspraktijk, als basis voor intercollegiale toetsing en voor het zichtbaar maken van de patiëntenzorg aan 'buitenstaanders'

- voor meer onderzoek naar interventies en methoden om werkelijke weranderingen in de zorg voor patiëriten te realiseren

- en voor een grotere investering in kwaliteitsbevordering in termen van geld, menskracht, opleiding en ondersteuning.

Het inwoeren van een kwaliteitssysteem mag men vergelijken met het inwoeren van een nieuwe, zeer complexe technologie $(45,46)$. Dat kast tijd en geduld. Het is goed als men zich realiseert dat Braille, die - zelf blind - in 1825 een revolutionair leesstysteem voor blinden ontwikkelde, er zo'n 50 jaar over deed om de zienden van de waarde van zijn uitvinding te overtuigen en zijn systeem in te voeren (47). Mijn werwachting is echter dat de huisartsgeneeskunde aanzienlijk slagvaardiger te werk zal gaan.

\section{DANKWOORD}

Gragg wil ik tenslotte de vele mensen en instanties bedanken die een bijdrage leverden of leveren an de realiseren wan mijn leerstoel en het werk wan de interuniversitaire werkgroep. 
Geache leden wan de Colleges wan Besmur en we besuren won de medishe facultetten wan

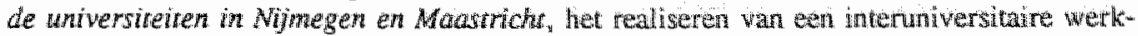
groep en een bijzondere leerstwel ab twee uniwersiteiten is nog geen dagelijks werk. U hebt daarin voortvarend en doeltreftend gehandeld en daarvoor wil uk U dank zeggen. Daarmee is de nogelijkheid geschapen een actueel en belangrigk thema binnen de hudige gezond heidszorg wetenschappelik tot ontwkkeling ta brengen. De onderzokkijnen en -zwaartepunten binnen de twee medische faculteiten en de complementare leerstoel kwaliteitsbevordering in de intramurale zorg te Maastricht bieden daarbij een vruchtbare voedingsbodem. Wi zullen er hard aan werken de verwachtingen in te lossen en hopen op een verdere ondersteuning van $U$ te mogen rekenen.

Leden wan bestum en direcrie en medewerkers wan het Nederlands Hüsarsen Genootschap. ik beschouw het als een bijzondere eer dat $\mathrm{k}$-als niet-huisarts- door de wetenschappelijke vereniging wan huisartsen als haar eerste hoogleraar ben benoemd. Het is naar mijn weten tevens de eerste leerstoel op het gebied van kwaliteisbevordering in de husartsgeneeskunde in de wereld. Ik beschouw deze beroeming ook als een blijk wan watudering voor de bijdrage die tal van sociale wetenschappers de afgelopen decennia aan hert bevorderen van de kwaliteit in de huisartsgeneeskunde hebben geleverd. Ik zal mij de komende jaren kractw tig inzetten om het kwaliteitsoeleid wan het Genootschap en haar partners te ondersteunen. Daarbij hoef ik mijzelf geen geweld aan te doen. Het Nederlands Muisartsen Genootschap oogt momenteel als eer vrouw van middelbare leefijd in haar tweede jeugd. Ze floreert en ziet er stralend wit. Het is een plezier harm te dienen.

Medewerkers van de Wenkgroep Onderzoek Kwalien̈ Husartsgeneeskunde, de WOK, exn WOK is een pan waarin werschillende ingrediënten worden gemengd tot er een smakelijk kwaliteitsgerecht kan worden opgediend. In onze Werkgroep zijn wij met zo'n 30 -40 mensen met uiteenlopende expertise aan het mengen en aan het werken aan kwaliteitsprodukten. Wij zijn met boeiende zaken bezig waar huisarisen behoefte aan hebben. Ik heb veel vertrouwen in de vitkomst van dit proces en zie met veel genoegen dat de samenwerking tussen Nijmegen en Mazstricht steeds meer vorm krijgt.

Hooggeleerde van Weel, Knonnerus, Crebolder en Van Ree, beste Chris, Andre, Harrie en Jan, dat ik jullie in bën zin noem heeft niet te maken met jullie eenvormigheid, Juist de diversiteit aan expertise warmee ik mij omringd weet maakt dat ik met veel enthousiasme aan dit samenwerkingsavontuur ben begonner. Ik reken op een lange en vructutbare samenwerking en wank jullie voor de steun die ik tot nu toe in grote mate heb gekregen.

Medewerkers en oud-nnedewerkers van de vakgroep huisantgenewskude we Ninmegen, ik werk bijna 15 jaar in jullie midden en daar heb ik mijn huidige vak geleerd. Werken in de opleiding tot huisarts, het wetenschappelijk onderzoek en de eerstelinspatiëntenzorg was een fancasische leerschool. Jullie steun en watdering heeft mij de prikkel en het zelfvertrouwen gegeven on steeds naar nieuwe wegen te zoeken. De fusie met sociale geneeskunde en de samenwerking in cen facultair onderzoekszwartepunt laten zien dat de tijo niet stil staat. Ik ben blij met de mieuwe mogelijkheden die dit bied.

Medewerkers van de Vakgroep Huisartsgeneeskunde te Mastrich, na bija wee jaar in jullie midden voel ik me goed thuis. Ik heb gemerkt hoe plezierig het werken is in een 
actieve groep van getalenteerde mensen. IK dank jullie voor de wijze waarop jullie mij en de interuniversitaire werkgroep op een naturlijke wijze hebben opgenomen.

Medewerkers van de Landelijke Hulsartsen Vereniging, het NIVEL, het IOH, het CBO, het Klinisch Trainings Centwom te Nijmegen, het Skillslab en de vakgroep Ondenwijsontwikkeling en Onderwijsresearch te Maasrich en andere organisaties en universitaire vakgroepen, waarmee inmiddels goede werkcontacten zijn gegroeid, het is een wan de noodzaken maar zelker ook een van de charmes van mijn werk dat het een nauwe samenwerking met tal van anderen buiten de directe werkomgeving met zich meebrengt. Al yoel ik mij soms een wat ontheende trekvogel, ik stel de samenwerking zeer op prijs en dank jullie hartelijk voor het wertrouwen in mij.

Geachte hüsantsopleiders en andere huisartsen, dankoij de medewerking van een zeez grote groep wan huisartisen uit onze regio's en daarbuiten zijn we in staat geweest te bereiken wat we hebben bereikt. Daarvoor mijn dank. Ik hoop dat we in de toekomst net zo succeswol kunnen samenwerken als in de afgelopen jaren.

Collega Tielens, beste Vic, sinds wij, in dezelfde tijd, ons werk bij de beroepsopleiding tot huisarts begonnen, ben jij voor mij een werkvriend en mentor geweest. Jouw kracht ligt in het -met grote bescheidenheid- tot bloei brengen van de talenten in anderen. Het is weldadig samen te werken met iemand die zo taai en zo onuitputtelijk optimistisch is. Ik vlei mij met de gedachte dat ik woor jou mogelijk even stimulerend was en ben als jij voor mij.

Collega Dubois, beste Vic, dat een andere drijwende kracht in mijn werkleven ook Vic heet zal well geen toeval zijn. Jouw visie op zaken is vaak slim of gewoon verstandig. Daar heb ik veel wan geleerd. Natuurlijk misgun ik je een rustige VUT niet, maar geef er de voorkeur aan je nog wat jaren om me heen te hebben.

Lieve Aimee, Meike en Edda, jullie will ik bedanken dat jullie me steeds weer met beide benen op de grond brengen. Dank zij jullie realiseer ik me dagelijks dat de kwaliteit van ons lewen niet noodzakelijkerwijs hetzelfde is als de kwaliteit in de huisartsgeneeskunde.

Ik heb gezegd.

Ik dank Harrie Crebolder, Vic Tielens, Vic Dubois, Chris van Weel, Andre Knottnerus en Willem Haaijman voor hun kritisch commentaar op deze rede en Agnes de Grunt voor haar bijdrage atan het definitieve mantiscript. 


\section{LITERATUUR}

1. Ministerie van WVC. Nota Kwaliteit van Zorg. Rijswijk; Stattsuitgeverij 1991.

2. Cromme P. Hoe warm is uw dokter? Huisarts Wet $1976 ; 19: 287-8$.

3. Stockem $T$ van. Is intercollegiale toetsing in de huisartsgeneeskunde zinvol? Huisarts Wet 1976; 288-91.

4. NHG. Naar criteria woor kwaliteit. Standaardenbeleid NHG. Utrecht: Nederlands Huisartsen Genootschap 1987.

5. Lamberts H. Hoe beïnvloedbaar is de huisarts? Huisarts Wet $1981 ; 24: 371-8,424-$ 30.

6. Grol R, Mesker P, red. Huisarts en Onderlinge Toetsing. Utrecht: Uitg. Bunge 1986.

7. Grol R. Kwaliteitsbewaking in de huisartsgeneeskunde. Diss. Katholieke Universiteit Nijmegen 1987.

8. NHG. Mededelingen en publicaties 1956;1 (1).

9. Harteloh P, Casparie A, Touw P. Kwaliteit van Zorg. Concepten en methoden. Intern rapport. Rotterdam; Erasmus Universiteit 1990.

10. Stolline A, Weiner J. The new medical marketplace. Baltimore: $J$ Hopkins Univ Press 1988.

11. Irvine D. Managing for quality in general practice. London: Kings Fund 1990.

12. Grol $R$, Heerdink $\mathbb{H}$. Verspreiding en acceptatie van NHG-standaarden. Utrecht: NHG-rapport 1991 (in druk).

13. Maeseneer I de, Meyboom- de Jong B. Niets is standaard in de huisartspraktijk (en zelfs dat niet). Huisarts Wet 1991; 34(1): 2-3.

14. McGuire L. A long run for a short jump: understanding clinical guidelines. Ann Int Med 1989; 113: 705-8.

15. Redelmeyer $D$, Tversiky A. Discrepancy between medical decisions for individual patients and for groups. N Engl J Med 1990; 322: 1162-4.

16. Berwick D. Continuous improwement as an ideal in health care. New Engl J Med 1989; 320: 53-6.

17. McGlynn E, Kosecoff J, Brook R. Format and conduct of consensus devellopment conferences. Multination comparison. Int J Techn Ass Health Care 1990; 6: 450-69. 
18. Audet A, Greenfield S, Field M. Medical practice guidelines: current activities and future directions. Arn Int Med 1990; 113:709-14.

19. Woolf $\$$. Practice guidelines: a new reality in medicine. Arch Int Med 1990; 150: $1811-8$.

20. Grol $\mathbb{R}$, Everdingen I van, Kuipers $F$, Casparie A. Consensus over consensus. Een kritische beschouwing van de procedure van $\mathrm{CBO}$-consensusontwikkeling. Ned Tijdschr Geneesk 1990; 134; 1186-9.

21. NHG. Werkboek Standaarden Ontwikkeling. Utrecht: Nederlands Huisartsengenootschap: 1990.

22. Grol $\mathbb{R}$. National Standard setting for quality of care in general practice: attitudes of general practitioners and response to a set of standards. Br I Gen Pract 1990; 40: $361-4$.

23. Eddy D. Practice policies: what are they? JAMA 1990; $263: 877-80$.

24. Leape L. Practice guidelines and standarcs. Qual Rev Bull 1990; 16: 42-9.

25. Farmer A. Setting up consensus standards for the care of patients in general practice. Br J Gen Pract 1991; 41: 135-6.

26. Field $\mathrm{M}$, Lohr $\mathrm{K}$, eds. Clinical practice guidelines: directions for a new agency. Institute of Medicine. Washington DC: Nat Acad Press 1990.

27. Fletcher R, Fletcher S. Clinical practice guidelines. Ann Int Med 1990; 113: 645-6.

28. Heitkoff $\mathrm{K}$, Lohr $\mathrm{K}$, eds. Effectiveness and outcomes in health care. Washington DC: Nat Acad Press 1990.

29. Skrabanek P. Nonsensus consensus. Lancet 1990; 335: 1447-7.

30. Höppener P, Knottnerus J, Grol R. Praktijkkautomatisering en kwaliteitsbewaking. Huisarts Wet 1990; 33(10): 390-3.

31. O'Leary D. Accreditation in the quality improvement mold-a vision for tomorrow. Qual Rev Bull 1991: 17: 72.6.

32. Berwick $\mathrm{D}$. Measuring and maintaining quality in a Health Maintenance Organization. In: Lohr $\mathrm{K}$, Rettig $\mathrm{R}$, eds. Quality of care and technology assessment. Washington DC: Nat Acad Press 1989.

33. Irvine D, Irvine S, eds. Making sense of audit. Oxford: Radcliffe Medical Press 1991. 
34. Difford F. Defining essential data for audit in general practice. Br Med J 1990; 300: 92-100.

35. Re $R_{*}$ Krousel-Wood $M$. Fow to use continuous quality improvement theory and statistical quality control tools in a multi-specialty clinic. Qual Rev Bull $1990 ; 16$ : $391-7$.

36. Tarlov A, Ware J, Greenfield $\mathrm{S}$, Nelson E, et al. The Medical Outcome Study. An application of methods for monitoring the results of medical care. JAMA 1989; 267: 925-30.

37. Pereira Gray D. Good general practice-fellowship of the RCGP by assessment. BrI Gen Pract 1991; 41: 182-3.

38. Essex B, Bate J. Audit in general practice by a receptionist: a feasibility study. $\mathrm{Br}$ Med J 1991; 302: $573-6$.

39. Lomas I, Haynes R. A taxonomy and critical review of tested strategies for the application of clinical practice recommendations: from "official" to "individual clinial policy'. In: Battista $R$, Lawrence $R$, eds. Implemting preventive services. Am I Prev Serv 1988; 4 : 77-95.

40. Sprij B, Casparie A, Grol R. Interventiemogelijkheden om een verandering in de medische praktijkvoring te bewerkstelligen. Wat is effectief? Ned Tijdschr Geneesk $1989 ; 133$ : $1115-7$.

41. Soumerai S, Mc Laughlin T, Avorn J. Quality assurance for drug prescribing. Qual Ass Health Care 1990; 2: 37-58.

42. Haynes R, Davis D, et al. A critical appraisal of the efficacy of continuing medical education. JAMA 1984; $251: 61-4$.

43. Woerkom $\mathrm{C}$ van. Voorlichting als beleidsinstrument: Nieuw en krachtig? Inaugurale rede. Landbouwuniversiteit Wageningen 1990.

44. Grol R. Bury M, Coumans $R$, Zwaard A. Deskundigheidsbevordering in huisartsgroepen: intercollegiale toetsing en invoering van siandaarden. Nüjmegen: WOK 1991.

45. Casparie A. Kwaliteit in de gezondheidszorg. Med Contact 1989; 44: 477-82.

46. Relman A. Assessement and accountability. The third rewolution in medical care. $\mathbb{N}$ Engl J Med 1988; 319: 1220-3.

47. Dunning A. Uitersten. Beschouwingen over menselijk gedrag. Amsterdam, Utrecht: Meulenhoff Nederland/ Wetenschappelijke Uikg Bunge 1990. 